\title{
In vitro determination of the anti-aging potential of four southern African medicinal plants
}

\author{
Gugulethu Ndlovu ${ }^{1,2^{*}}$, Gerda Fouche ${ }^{1}$, Malefa Tselanyane ${ }^{3}$, Werner Cordier ${ }^{4}$ and Vanessa Steenkamp ${ }^{4^{*}}$
}

\begin{abstract}
Background: Aging is an inevitable process for all living organisms. During this process reactive oxygen species generation is increased which leads to the activation of hyaluronidase, collagenase and elastase, which can further contribute to skin aging. Four southern African medicinal plants; Clerodendrum glabrum, Schotia brachypetala, Psychotria capensis and Peltophorum africanum, were investigated to assess their anti-aging properties.

Methods: Anti-elastase, anti-collagenase and anti-hyaluronidase activities of twenty-eight samples, consisting of methanol and ethyl acetate extracts of the four plants, were determined using spectrophotometric methods. Radical scavenging activity was determined by the ability of the plant extracts to scavenge the ABTS ${ }^{++}$radical.

Results: The majority of the samples in the anti-elastase assay and nine in the anti-collagenase assay showed more than $80 \%$ inhibition. The ethyl acetate extract of $S$. brachypetala bark and leaves of $P$. capensis inhibited elastase activity by more than $90 \%$. The methanol extract of $S$. brachypetala bark contained the highest anti-hyaluronidase activity $(75.13 \pm 7.49 \%)$ whilst the ethyl acetate extract of $P$. africanum bark exhibited the highest antioxidant activity $\left(\mathrm{IC}_{50}: 1.99 \pm 0.23 \mu \mathrm{g} / \mathrm{ml}\right)$.

Conclusion: The free radical scavenging activity and enzyme inhibitory activity of the plant extracts investigated suggests that they can help restore skin elasticity and thereby slow the wrinkling process. P. africanum was the plant with the most promising activity and will be subjected to further testing and isolation of the active compound/s.
\end{abstract}

Keywords: Anti-aging, Anti-collagenase, Anti-elastase, Anti-hyaluronidase, Anti-oxidant, Medicinal plants

\section{Background}

Aging is an inevitable process for all living organisms. In humans the skin is the tissue most markedly affected. Two types of skin aging exist: age-dependent/chronological aging and premature aging/photoaging [1]. The latter is caused by extrinsic factors and includes signs such as a leathery appearance, dark/light pigmentation and deep furrows $[2,3]$. Natural aging is visible as wrinkling of the skin.

The skin is divided into three layers; the epidermis, dermis and subcutaneous tissue [4]. The extracellular matrix (ECM) is the outermost part of the skin and is composed of amongst others fibroblasts and proteins including collagen and elastin [5]. The ECM provides a structural framework

\footnotetext{
* Correspondence: gndlovu1@csir.co.za; vanessa.steenkamp@up.ac.za 'Natural Product Chemistry Group, Biosciences Unit, Council for Scientific and Industrial Research, P.O. Box 395, Pretoria (0001), South Africa ${ }^{4}$ Department of Pharmacology, University of Pretoria, Private Bag X323, Arcadia (0007), South Africa

Full list of author information is available at the end of the article
}

which is essential for growth and elasticity of the skin and plays an important role in the maintenance of physiological functions of the body [5,6]. Degradation of the ECM has directly been linked to skin aging and is correlated with an increase in activity of certain enzymes involved in skin aging, which includes hyaluronidase, elastase and collagenase $[3,7,8]$.

Collagen, one of the major building blocks of the skin, is the main component of connective tissue, hair and nails [1]. It is responsible for the elasticity and strength of the skin and maintains its flexibility. Hyaluronic acid plays a role in retaining the moisture of the skin, as well as its structure and elasticity. It also facilitates the exchange of nutrients and waste products and is involved in rapid tissue proliferation, regeneration and repair $[9,10]$. This compound is also involved in organisation and structural maintenance of the ECM [9]. With aging, collagen, elastin and hyaluronic acid levels decrease, leading to a loss

\section{Biomed Central}

(c) 2013 Ndlovu et al.; licensee BioMed Central Ltd. This is an open access article distributed under the terms of the Creative Commons Attribution License (http://creativecommons.org/licenses/by/2.0), which permits unrestricted use, distribution, and reproduction in any medium, provided the original work is properly cited. 
of strength and flexibility in the skin which results in visible wrinkles.

Reactive oxygen species (ROS) play an important role in many cellular mechanisms [11]. When UV radiation is absorbed by the skin it leads to increased ROS generation and induction of oxidative stress. Oxidative damage may lead to lipid peroxide formation, mitochondrial and DNA damage, and protein and gene modification which alter protein structure and function [12]. High levels of ROS lead to the activation of hyaluronidase, collagenase and elastase, which can further contribute to skin aging $[1,4,13]$.

Plants have long been used in the cosmetic industry as amongst others, skin lighteners and sun-screen agents. In vitro scientific studies have shown that plants possess the ability to reduce antioxidant levels and inhibit hyaluronidase, collagenase, elastase and tyrosinase activity $[10,11,14]$.

People living on the African continent are exposed to the harsh sun and rarely use skin protective agents as they are expensive. It is for this reason that plants which are readily accessible be explored for their potential use as anti-aging reagents. Four plants were selected to assess their anti-collagenase, anti-hyaluronidase, antielastase and anti-oxidant activity. Traditionally, Peltophorum africanum (Fabaceae) is used to treat wounds [15], Schotia brachypetala to wash the body, reduce body swelling, steam the face, treat tropical ulcers and as an emetic for pimples [16], Clerodendrum glabrum to treat snakebites [17] and Psychotria capensis (Rubiaceae) to treat gastric complaints [18]. Selection of the plants was based on either its indigenous facial use; $S$ brachypetala, its topical application to wounds; $P$. africanum or due to its good antioxidant activities exhibited in previous studies carried out in this laboratory (unpublished data); C. glabrum and P. capensis.

\section{Methods}

\section{Chemicals and reagents}

N-Methoxysuccinyl-Ala-Ala-Pro-Val-p-nitroanilide, human leukocyte elastase, 4-(2-hydroxyethyl)-1-piperazineethanesulfonic acid (HEPES, pH 7.5), sodium chloride, dimethysulfoxide (DMSO), N-Methoxysuccinyl-Ala-Ala-Pro-Chloro, elafin, N-[3-(2-furyl)acryloyl]-Leu-Gly-Pro-Ala (FALGPA), tris(hydroxymethyl)-methyl-2-aminoethane sulfonate (TES), calcium chloride dihydrate, ethylenediaminetetraacetic acid (EDTA), ninhydrin, citric acid, tin (II) chloride, 2-propanol, hyaluronic acid sodium salt from Streptococcus equi, bovine testicular hyaluronidase, potassium metaborate $\left(\mathrm{KBO}_{2}\right)$, 4dimethylaminobenzaldehyde (DMAB), sodium aurothiomalate, 2,2'-azinobis-3-ethyl benzothiazoline 6-sulfonic acid (ABTS), potassium peroxidisulfate and 6-hydroxy2,5,7,8-tetramethylchroman-2-carboxylic acid (trolox) were procured from Sigma. Bovine serum albumin and collagenase type 1 from Clostridium histolyticum were purchased from Life Technologies, whereas methanol $(\mathrm{MeOH})$ and ethyl acetate (EtOAc) were purchased from Merck.

\section{Plant collection and extract preparation}

The plants investigated in this study are listed in Table 1. Specimens were collected by a botanist and the identity confirmed by the South African National Biodiversity Institute (SANBI, Tshwane) where voucher specimens are deposited. Voucher numbers are provided in Table 1.

Plants were dried in an oven at $30-60^{\circ} \mathrm{C}$ and ground (1 mm) using a baby hippo hammer mill (A Collins \& Son Pty. Ltd.). Ground plant material (20 g) was extracted with either EtOAc or $\mathrm{MeOH}$ using a Buchi Accelerated Speed Extractor E916. These solvents were selected based on reports of high extraction efficiency of antioxidants $[19,20]$. Resultant extracts were evaporated under vacuum at $40^{\circ} \mathrm{C}$ and stored at $4{ }^{\circ} \mathrm{C}$ until use. The extract yields were determined gravimetrically (Table 1 ).

\section{Determination of anti-elastase activity}

Anti-elastase activity was determined according to the method of Kraunsoe et al. [21], with minor modifications. Into 96-well plates was added: $25 \mu \mathrm{l}$ each of $0.1 \mathrm{M}$ HEPES buffer ( $\mathrm{pH} 7.5)$, test sample $(1.4 \mathrm{mg} / \mathrm{ml})$ and elastase $(1 \mu \mathrm{g} / \mathrm{ml})$. The blank wells contained HEPES buffer $(75 \mu \mathrm{l})$, the negative control $25 \mu \mathrm{l}$ elastase and $50 \mu \mathrm{l}$ HEPES buffer. The positive controls received $25 \mu$ leach of elastase, HEPES buffer and elafin/ $\mathrm{N}$-methoxysuccinylAla-Ala-Pro-Chloro $(10 \mu \mathrm{g} / \mathrm{ml})$. The solvent controls contained $25 \mu \mathrm{l}$ each of elastase, HEPES buffer and either $10 \% \mathrm{MeOH}, 10 \%$ DMSO or $30 \%$ DMSO depending on the solvent the test sample was dissolved in. Extract controls containing $150 \mu \mathrm{l}$ HEPES buffer and $25 \mu \mathrm{l}$ of the extract were colour controls of each extract tested. Plates were incubated at room temperature for $20 \mathrm{~min}$ after which $100 \mu \mathrm{l}$ of the substrate N-MethoxysuccinylAla-Ala-Pro-Val-p-nitroanilide $(1 \mathrm{mM})$ was added and the plates incubated for a further $40 \mathrm{~min}$ at $25^{\circ} \mathrm{C}$. Absorbance was read at $405 \mathrm{~nm}$ using a Tecan Infinite 500 spectrophotometer. The percentage inhibition was calculated as follows:

$$
\text { Inhibition }(\%)=\left[\left(A_{\text {control }}-A_{\text {test sample }}\right) / A_{\text {control }}\right] \times 100
$$

Where $A_{\text {control }}$ is the absorbance of buffer, elastase + solvent and $\mathrm{A}_{\text {sample }}$ is the absorbance of buffer, elastase + extract or elafin/ N-Methoxysuccinyl-Ala-Ala-Pro-Chloro.

\section{Determination of anti-collagenase activity}

The method of Moore and Stein [22] with modifications by Mandl et al. [23] was used to determine anticollagenase activity. To $2 \mathrm{ml}$ test tubes was added: $25 \mu \mathrm{l}$ each of collagenase $(1 \mathrm{mg} / \mathrm{ml})$, TES buffer $(50 \mathrm{mM})$ with 
Table 1 Plants, voucher number, plant parts and percentage yields of investigated specimens

\begin{tabular}{|c|c|c|c|c|c|}
\hline \multirow[t]{2}{*}{ Plant species (Family) } & \multirow[t]{2}{*}{ Vernacular } & \multirow{2}{*}{$\begin{array}{l}\text { Voucher } \\
\text { number }\end{array}$} & \multirow[t]{2}{*}{ Plant part } & \multicolumn{2}{|c|}{$\%$ Yield } \\
\hline & & & & $\mathrm{MeOH}$ & EtOAc \\
\hline \multirow[t]{4}{*}{ Clerodendrum glabrum E. Mey var. glabrum (Verbenaceae) } & Tinderwood & PRE 7554 & Roots & 4.99 & 1.77 \\
\hline & & & Stems & 5.44 & 0.63 \\
\hline & & & Fruits & 10.5 & 1.15 \\
\hline & & & Bark & 5.19 & 1.00 \\
\hline \multirow[t]{4}{*}{ Peltophorum africanum Sond. (Fabaceae) } & African wattle & PRE 180 & Leaves & 14.7 & 1.37 \\
\hline & & & Seeds & 9.56 & 3.58 \\
\hline & & & Bark & 18.5 & 2.64 \\
\hline & & & Stems & 7.49 & 1.03 \\
\hline \multirow[t]{3}{*}{ Psychotria capensis (Eckl.) Vatke sub. capensis var. capensis (Rubiaceae) } & Lemon bush & PRE 3047 & Leaves & 27.0 & 2.82 \\
\hline & & & Stems & 7.00 & 0.46 \\
\hline & & & Seeds & 11.9 & 1.60 \\
\hline \multirow[t]{2}{*}{ Schotia brachypetala Sond. (Fabaceae) } & African walnut & PRE 324 & Bark & 36.4 & 0.64 \\
\hline & & & Leaves & 4.74 & 4.09 \\
\hline
\end{tabular}

$0.36 \mathrm{mM}$ calcium chloride ( $\mathrm{pH} 7.4$ ) and test sample (1.4 $\mathrm{mg} / \mathrm{ml}$ ). The blank contained $75 \mu \mathrm{l}$ TES buffer, while the negative control contained $25 \mu \mathrm{l}$ collagenase and $50 \mu \mathrm{l}$ TES buffer. The positive control contained $25 \mu \mathrm{l}$ collagenase, $25 \mu \mathrm{l}$ each of TES buffer and EDTA $(1 \mathrm{mg} / \mathrm{ml})$. The solvent control contained equal amounts $(25 \mu \mathrm{l})$ of collagenase, TES buffer and either $10 \% \mathrm{MeOH}$, $10 \%$ DMSO or $30 \%$ DMSO depending on the solvent the test sample was dissolved in. The tubes were incubated in a water bath at $37^{\circ} \mathrm{C}$ for $20 \mathrm{~min}$. Thereafter, $100 \mu \mathrm{l}$ FALGPA was added to the tubes and incubated further for $60 \mathrm{~min}$ at $37^{\circ} \mathrm{C}$. To all tubes, $200 \mu \mathrm{l}$ of a solution containing equal volumes of $200 \mathrm{mM}$ citrate buffer $(\mathrm{pH} 5)$ and ninhydrin solution was added. All tubes were placed in a water bath $\left(100^{\circ} \mathrm{C}\right)$ for $5 \mathrm{~min}$ and left to cool to room temperature before adding $200 \mu \mathrm{L}$ of $50 \%$ isopropanol to each tube. Contents in the tubes were then transferred to respective wells in 48-well plates. Absorbance was detected at $540 \mathrm{~nm}$ using a Tecan Infinite 500 spectrophotometer. The percentage inhibition was calculated using a formula similar to that in the previous section where $A_{\text {control }}$ is the absorbance of buffer, collagenase + solvent and $\mathrm{A}_{\text {sample }}$ is the absorbance of buffer, collagenase + extract or EDTA.

\section{Determination of anti-hyaluronidase activity}

The fluorimetric Morgan-Elson assay method of Reissig et al. [24] as modified by Takahashi et al. [25] was followed. Into $2 \mathrm{ml}$ test tubes was placed: $25 \mu \mathrm{l}$ of calcium chloride $(12.5 \mathrm{mM}), 12.5 \mu \mathrm{l}$ each of test samples $(2.8 \mathrm{mg} / \mathrm{ml})$ and hyaluronidase $(1.5 \mathrm{mg} / \mathrm{ml})$. The blank contained $25 \mu \mathrm{l}$ distilled water, the negative control $12.5 \mu \mathrm{l}$ distilled water, the positive control $12.5 \mu \mathrm{l}$ of sodium aurothiomalate $(2.8 \mathrm{mg} / \mathrm{ml})$ and the solvent control $12.5 \mu \mathrm{l}$ of either $100 \%$ DMSO or $\mathrm{MeOH}$. All the tubes except the blank received $12.5 \mu \mathrm{l}$ of the enzyme. The tubes were incubated in a water bath $\left(37^{\circ} \mathrm{C} ; 20 \mathrm{~min}\right)$ after which $100 \mu \mathrm{l}$ of the substrate hyaluronic acid $(1 \mathrm{mg} / \mathrm{ml}$ in $0.1 \mathrm{M}$ acetate buffer; $\mathrm{pH} 3.5$ ) was added and the tubes incubated further for $40 \mathrm{~min}$. Twenty-five microlitres $\mathrm{KBO}_{2}(0.8 \mathrm{M})$ was added to all tubes and the tubes were placed in a water bath $\left(100^{\circ} \mathrm{C}\right)$ for $3 \mathrm{~min}$, left to cool to room temperature and $800 \mu \mathrm{l}$ of DMAB (4 g DMAB in $40 \mathrm{ml}$ acetic acid and $5 \mathrm{ml} 10 \mathrm{~N} \mathrm{HCl}$ ) was added. The tubes were then incubated for $20 \mathrm{~min}$ and the contents transferred to respective wells in a 48-well plate. Fluorescence was detected using a Tecan Infinite 500 spectrophotometer at $545 \mathrm{~nm}$ excitation and $612 \mathrm{~nm}$ emission. The percentage inhibition was calculated using the same formula provided earlier. Where $\mathrm{A}_{\text {control }}$ is the absorbance of buffer, hyaluronidase + solvent and $A_{\text {sample }}$ is the absorbance of buffer, hyaluronidase + extract or sodium aurothiomalate.

\section{$\mathrm{ABTS}^{*+}$ radical scavenging activity}

The trolox equivalent antioxidant assay was used to determine the ABTS $^{\cdot+}$ scavenging ability of the crude extracts, as reported by $\mathrm{Re}$ et al. [26]. Briefly, ABTS ${ }^{\cdot+}$ (7.46 $\mathrm{mM})$ was prepared in distilled water and oxidized using $2.5 \mathrm{mM}$ potassium peroxidisulfate at $4^{\circ} \mathrm{C}$ for $16 \mathrm{~h}$. The oxidized solution was diluted with distilled water to an absorbance of $0.70 \pm 0.02$ at $734 \mathrm{~nm}$. Into a 96-well plate was added $20 \mu \mathrm{l}$ Trolox $(0 ; 0.0125 ; 0.04 ; 0.06 ; 0.075$; $0.1 \mathrm{mg} / \mathrm{ml})$ or $20 \mu \mathrm{l}$ crude extracts $(0.01 ; 0.032 ; 0.1 ; 0.32$ and $1 \mathrm{mg} / \mathrm{ml}$ ), and $180 \mu \mathrm{ABTS}^{\circ+}$. Plates were incubated for $15 \mathrm{~min}$ in the dark after which absorbance was measured at $405 \mathrm{~nm}$ using an ELx 800 UV universal microplate reader. The $\mathrm{ABTS}^{*+}$ scavenging capacity of extracts 
was compared to that of trolox and the percentage inhibition calculated using the following formula:

$$
\begin{aligned}
& \text { ABTS radical scavenging activity }(\%) \\
& \quad=\left[\left(A_{\text {control }}-A_{\text {sample }}\right) / A_{\text {control }}\right] \times 100
\end{aligned}
$$

$\mathrm{A}_{\text {control }}$ is the absorbance of $\mathrm{ABTS}^{*+}+$ solvent and $\mathrm{A}_{\text {sample }}$ is the absorbance of ABTS radical + extract or trolox.

\section{Statistical procedures}

Tests were carried out in triplicate on two different occasions for the enzyme assays and on at least three occasions for the antioxidant assay. The results are presented as mean \pm standard deviation $(\mathrm{SD})$. $\mathrm{IC}_{50}$ values, which represent the concentration of the extract required to scavenge half the $\mathrm{ABTS}^{\circ+}$ radical, for the antioxidant assay were determined using GraphPad Prism Version 4.00 for windows.

The data for the enzyme assays was analyzed using MS Excel. The results are expressed as percentage inhibition. The percentage inhibitions were subjected to an appropriate analysis of variance (ANOVA) with the three enzymes as the main plot factor plus combinations of (the two solvents $\times$ six plant parts $\times$ four plant species $\times$ the positive controls) as sub-plot factors. The standardized residuals were tested for deviations from normality using the Shapiro-Wilk test [27]. The analyses were performed using SAS version 9.2 statistical software [28].

Research ethics forms were filled in and submitted to the ethics committee at the Council for Scientific and Industrial Research (South Africa). The committee approved the study stating that no ethics approval was required for this study.

\section{Results and discussion}

C. glabrum (roots, stems, fruits and bark), S. brachypetala (leaves and bark), $P$. africanum (leaves, seeds, bark and stems) and $P$. capensis (leaves, stems and seeds) were investigated to determine the anti-aging potential of these plants with regards to anti-elastase, anti-hyaluronidase and anti-collagenase activity as well as antioxidant activity.

Statistical analyses of the results showed that deviations from normality $(\mathrm{p}<0.001)$ were caused by Kurtosis not skewness, therefore the results were taken as normal [29]. From ANOVA the four factor interactions, mentioned in the statistical procedures section, were highly significant $(\mathrm{p}<0.001)$. The mean percentage inhibitions are presented in Table 2 and the Student's t.LSD (least significant difference) were calculated at $5 \%$ level of significance (t.LSD $=0.05=8.7146$ ) to compare the means with a pooled variance of 16.5565 and 81 degrees of freedom.

\section{Anti-elastase assay}

Elastin is a protein found in connective tissue which is responsible for the elasticity of the skin and lungs $[5,6,30]$. This protein is catalysed by the enzyme elastase. Degradation of elastin by intracellular elastase increases with age and/or repeated UV-radiation, leading to skin aging $[5,6,13]$. Twelve of the samples inhibited elastase by $\geq 80 \%$ (Table 2). The ethyl acetate extracts of $P$. capensis leaves $(92.84 \pm 1.13 \%)$ and S. brachypetala bark $(93.73 \pm 0.51 \%)$ had higher activity than N-Methoxysuccinyl-Ala-Ala-ProChloro (91.54 $\pm 4.14 \%$ ), and comparable activity to elafin $(93.09 \pm 4.10 \%)$. The solvents had a negligible effect on elastase activity.

To the knowledge of the authors, the elastase inhibitory activity of the four plants has not been reported before. However, the anti-elastase activity of plant species belonging to the same families as the studied plants has been reported. Coffea arabica (Fabaceae) leaf extracts have been reported to exhibit anti-elastase activity [28]. Hedyotis diffusa (synonym Oldenlandia diffusa, family Rubiaceae) has been found to inhibit human neutrophil elastase activity [31]. A phenanthrenedione, pterolinus $\mathrm{K}$, and a chalcone (pterolinus L) from the heartwood of Pterocarpus santalinus (Fabaceae) were found to inhibit generation of the superoxide anion and the release of elastase [32] and iridoid glycoside esters isolated from the aerial methanol extract of Ixora coccinea (Rubiaceae) inhibited the release of elastase [33]. The anti-elastase activity of the family Verbanaceae has not been reported as yet.

\section{Anti-collagenase activity}

Collagen, the major component of the skin, is degraded by the enzyme collagenase. Inhibition of collagenase activity delays the process of forming pre-collagen fibres and subsequently the wrinkling process [1]. Twenty-two extracts inhibited the enzyme by more than $50 \%$, with nine of these inhibiting the enzyme by more than $80 \%$ (Table 2). The ethyl acetate extracts of C. glabrum stems and $P$. africanum bark and stems and S. brachypetala bark and leaves contained activity higher than the positive control, EDTA $(83.75 \pm 2.89 \%)$.

The anti-collagenase activity of the studied plants has not been reported previously. No information was found regarding the collagenase inhibition activity of plants belonging to the Verbanaceae and Rubiaceae families. In the Fabaceae family, Coffea arabica leaf extracts have been shown to inhibit collagenase- 1 activity in a dosedependent fashion [34].

\section{Anti-hyaluronidase activity}

The methanol bark extract of S. brachypetala inhibited hyaluronidase activity the most, $75.13 \pm 7.49 \%$. Methanol leaf extracts of $P$. capensis and bark of $P$. africanum as 
Table 2 The effect of the plant extracts $(200 \mu \mathrm{g} / \mathrm{ml})$ on enzyme activities

\begin{tabular}{|c|c|c|c|c|c|}
\hline Plant species & Plant part & Extract type & Anti-elastase & Anti-collagenase & Anti-hyaluronidase \\
\hline \multirow[t]{8}{*}{ Clerodendrum glabrum } & roots & $\mathrm{MeOH}$ & $5.92 \pm 4.75$ & $\mathrm{ng}$ & $\mathrm{ng}$ \\
\hline & & EtOAc & $15.30 \pm 1.96$ & $31.70 \pm 0.54$ & $\mathrm{ng}$ \\
\hline & stems & $\mathrm{MeOH}$ & $13.35 \pm 0.56$ & $68.09 \pm 8.57$ & $\mathrm{ng}$ \\
\hline & & EtOAc & $89.38 \pm 3.24$ & $88.64 \pm 0.53$ & $8.11 \pm 0.95$ \\
\hline & fruits & $\mathrm{MeOH}$ & $49.38 \pm 3.82$ & $72.54 \pm 9.83$ & $0.51 \pm 0.72$ \\
\hline & & EtOAc & $87.95 \pm 0.10$ & $26.29 \pm 1.17$ & $2.50 \pm 3.53$ \\
\hline & bark & $\mathrm{MeOH}$ & $13.52 \pm 6.96$ & $58.96 \pm 8.65$ & $5.19 \pm 1.61$ \\
\hline & & EtOAc & $81.46 \pm 4.78$ & $81.55 \pm 4.03$ & $\mathrm{ng}$ \\
\hline \multirow[t]{8}{*}{ Peltophorum africanum } & leaves & $\mathrm{MeOH}$ & $55.83 \pm 0.04$ & $82.13 \pm 3.64$ & $49.32 \pm 6.58$ \\
\hline & & $\mathrm{EtOAc}$ & $80.20 \pm 1.02$ & $75.26 \pm 7.38$ & $2.69 \pm 3.80$ \\
\hline & seeds & $\mathrm{MeOH}$ & $85.17 \pm 3.20$ & $80.39 \pm 9.18$ & $\mathrm{ng}$ \\
\hline & & EtOAc & $87.09 \pm 1.22$ & $77.34 \pm 4.45$ & $2.18 \pm 0.13$ \\
\hline & bark & $\mathrm{MeOH}$ & $69.36 \pm 4.33$ & $78.44 \pm 3.18$ & $48.46 \pm 6.77$ \\
\hline & & EtOAc & $86.27 \pm 3.63$ & $88.27 \pm 1.77$ & $23.24 \pm 0.18$ \\
\hline & stems & $\mathrm{MeOH}$ & $64.50 \pm 3.41$ & $74.14 \pm 1.08$ & $0.95 \pm 0.76$ \\
\hline & & EtOAc & $84.40 \pm 3.97$ & $83.25 \pm 3.57$ & $13.78 \pm 0.28$ \\
\hline \multirow[t]{8}{*}{ Psychotria capensis } & roots & $\mathrm{MeOH}$ & $45.90 \pm 9.84$ & $59.41 \pm 6.73$ & $12.86 \pm 3.42$ \\
\hline & & EtOAc & $59.60 \pm 7.57$ & $28.42 \pm 5.23$ & $2.28 \pm 3.22$ \\
\hline & stems & $\mathrm{MeOH}$ & $42.98 \pm 7.29$ & $56.45 \pm 9.26$ & $5.00 \pm 0.69$ \\
\hline & & EtOAc & $56.58 \pm 2.11$ & $29.98 \pm 0.81$ & $\mathrm{ng}$ \\
\hline & leaves & $\mathrm{MeOH}$ & $3.28 \pm 4.63$ & $\mathrm{ng}$ & $52.98 \pm 0.66$ \\
\hline & & $\mathrm{EtOAc}$ & $92.84 \pm 1.13$ & $63.07 \pm 9.15$ & $3.13 \pm 4.42$ \\
\hline & seeds & $\mathrm{MeOH}$ & $44.16 \pm 2.99$ & $78.36 \pm 1.50$ & $\mathrm{ng}$ \\
\hline & & $\mathrm{EtOAC}$ & $70.67 \pm 4.80$ & $69.48 \pm 5.91$ & $\mathrm{ng}$ \\
\hline \multirow[t]{4}{*}{ Schotia brachypetala } & bark & $\mathrm{MeOH}$ & $75.32 \pm 6.91$ & $77.51 \pm 0.28$ & $75.13 \pm 7.49$ \\
\hline & & EtOAc & $93.73 \pm 0.51$ & $87.61 \pm 6.72$ & $\mathrm{ng}$ \\
\hline & leaves & $\mathrm{MeOH}$ & $82.54 \pm 3.01$ & $81.35 \pm 2.52$ & $20.36 \pm 1.92$ \\
\hline & & $\mathrm{EtOAC}$ & $84.22 \pm 4.79$ & $84.70 \pm 1.33$ & $6.29 \pm 1.17$ \\
\hline \multicolumn{6}{|l|}{ Controls $(10 \mu \mathrm{g} / \mathrm{ml})$} \\
\hline Elafin & & & $93.09 \pm 4.10$ & N/A & N/A \\
\hline N-Methoxysuccinyl-Ala-Ala-Pro-Chloro & & & $91.54 \pm 4.14$ & N/A & N/A \\
\hline EDTA & & & $\mathrm{N} / \mathrm{A}$ & $83.75 \pm 2.89$ & N/A \\
\hline Sodium aurothiomalate & & & N/A & N/A & $100 \pm 0.01$ \\
\hline
\end{tabular}

Results are given as percentage inhibition \pm Standard Deviation, t.LSD (least significant difference) $)_{p=0.05}=8.7146$. Some extracts showed negligible enzyme activity $(<0.01 \%)$ and these are represented by $\mathrm{ng}, \mathrm{N} / \mathrm{A}$ represents not applicable.

well as ethyl acetate leaf extracts of this plant contained noticeable inhibitory activity (Table 2 ). The positive control, sodium aurothiomalate, completely inhibited the activity of hyaluronidase.

The anti-hyaluronidase activity of plants belonging to the Rubiaceae and Verbenaceae families has not been reported to date. The aqueous stem-bark extract of Caesalpinia paraguariensis (Fabaceae) has been reported to inhibit hyaluronidase [35]. Leaf extracts of Astragalus membranaceus are reported to increase the content of hyaluronic acid in cultured keratinocytes and fibroblasts by increasing mRNA expressions of hyaluronan synthase3 and hyaluronan synthase-2 [10].

\section{Antioxidant activity}

The concentration at which the extracts were able to scavenge half of the $\mathrm{ABTS}^{*+}$ radical $\left(\mathrm{IC}_{50}\right)$ is presented in Table 3. The lower the $\mathrm{IC}_{50}$ value, the stronger antioxidant activity. Ethyl acetate extracts of the bark of $P$. africanum showed activity comparable to that of the positive control, trolox ( $\left.\mathrm{IC}_{50} 2.0 \pm 0.23 \mu \mathrm{g} / \mathrm{ml}\right)$. Antioxidant activity has been reported for the acetone extract of 
Table 3 Antioxidant activity of tested extracts

\begin{tabular}{|c|c|c|c|}
\hline Plant name & Plant part & Extract type & $\mathrm{IC}_{50} /(\mu \mathrm{g} / \mathrm{mL})^{*}$ \\
\hline \multirow[t]{8}{*}{ Clerodendrum glabrum } & Roots & $\mathrm{MeOH}$ & $21.1 \pm 1.72$ \\
\hline & & EtOAc & $17.8 \pm 6.47$ \\
\hline & Stems & $\mathrm{MeOH}$ & $17.0 \pm 1.96$ \\
\hline & & EtOAc & $9.90 \pm 3.27$ \\
\hline & Bark & $\mathrm{MeOH}$ & $10.8 \pm 0.99$ \\
\hline & & EtOAc & $\mathrm{ng}$ \\
\hline & Fruits & $\mathrm{MeOH}$ & $35.5 \pm 4.01$ \\
\hline & & EtOAc & $63.9 \pm 5.03$ \\
\hline \multirow[t]{8}{*}{ Peltophorum africanum } & Leaves & $\mathrm{MeOH}$ & $5.3 \pm 0.72$ \\
\hline & & EtOAc & $9.2 \pm 0.76$ \\
\hline & Seeds & $\mathrm{MeOH}$ & $7.16 \pm 0.93$ \\
\hline & & EtOAc & $11.4 \pm 2.48$ \\
\hline & Bark & $\mathrm{MeOH}$ & $4.9 \pm 0.47$ \\
\hline & & EtOAc & $2.0 \pm 0.23$ \\
\hline & Stems & $\mathrm{MeOH}$ & $4.5 \pm 0.38$ \\
\hline & & EtOAc & $2.1 \pm 0.17$ \\
\hline \multirow[t]{8}{*}{ Psychotria capensis } & Stems & $\mathrm{MeOH}$ & $11.3 \pm 1.90$ \\
\hline & & EtOAc & $52.0 \pm 15.30$ \\
\hline & Roots & $\mathrm{MeOH}$ & $9.6 \pm 0.73$ \\
\hline & & EtOAc & $9.5 \pm 1.06$ \\
\hline & Leaves & $\mathrm{MeOH}$ & $68.3 \pm 8.87$ \\
\hline & & EtOAc & $62.3 \pm 6.00$ \\
\hline & Seeds & $\mathrm{MeOH}$ & $25.8 \pm 2.72$ \\
\hline & & EtOAc & $23.9 \pm 4.57$ \\
\hline \multirow[t]{4}{*}{ Schotia brachypetala } & Bark & $\mathrm{MeOH}$ & $2.8 \pm 0.31$ \\
\hline & & EtOAc & $7.7 \pm 0.55$ \\
\hline & Leaves & $\mathrm{MeOH}$ & $7.8 \pm 0.63$ \\
\hline & & EtOAc & $50.3 \pm 9.33$ \\
\hline Trolox & N/A & N/A & $2.84 \pm 0.52$ \\
\hline
\end{tabular}

*Results are given as $\mathrm{IC}_{50} \pm \mathrm{SD} \mathrm{ng}=$ extracts had negligible antioxidant activity.

the root and bark of P. africanum [15]. Other Peltophorum species with reported antioxidant activity include: $P$. pterorcarpum, P. ferrugineum, and P. dubium [36-38].

Extracts of C. glabrum contained moderate antioxidant activity. Antioxidant activity and free radical scavenging activity has been reported for various Clerodendrum species: C. infortunatum [39], C. siphonathus [40] and C. glandulosum [41]. The antioxidant activity noted for the methanol and ethyl acetate bark extracts of $S$. brachypetala is supported by studies where antioxidant and hydroxyl radical scavenging activity have been reported for the aqueous bark extracts of this plant $[42,43]$. Isolated compounds from this plant with known antioxidant activity include stilbenes and phenolics [44].

The root extracts of $P$. capensis contained antioxidant activity $<10 \mu \mathrm{g} / \mathrm{ml}$. Although the antioxidant activity of this plant species has not previously been reported, the antioxidant activity of extracts from other Psychotria species are known; P. brachyceras, $P$. umbellata, $P$. serpens, and $P$. rostrata [45-47].

\section{Conclusion}

This is the first study to investigate the anti-elastase, anticollagenase and anti-hyaluronidase activity of C. glabrum, $P$. capensis, $P$. africanum and S. brachypetala. The free radical scavenging activity and enzyme inhibitory activity of the plant extracts suggests that they can help restore skin elasticity and thereby slow the wrinkling process. $P$. africanum was the plant with the most promising activity and will be subjected to further testing and isolation of the active compound/s.

\section{Abbreviations \\ DMSO: Dimethysulfoxidel; FALGPA: N-[3-(2-Furyl)acryloyl]-Leu-Gly-Pro-Ala; TES: Tris(hydroxymethyl)-methyl-2-aminoethane sulfonate; EDTA: Ethylenediaminetetraacetic acid; $\mathrm{KBO}_{2}$ : Potassium metaborate; DMAB: 4-dimethylaminobenzaldehyde; ABTS: 2,2'-azinobis-3-ethyl benzothiazoline 6-sulfonic acid; trolox: 6-hydroxy-2,5,7,8-tetramethylchroman- 2-carboxylic acid; MeOH: Methanol; EtOAc: Ethyl acetate. \\ Competing interests \\ The authors declare that they have no competing interests. \\ Authors' contributions \\ GN was involved in both the antioxidant and enzyme assays and in drafting the manuscript. WC was involved in the ABTS including preparing reagents, running and analysing the data. MT helped with running and analysis of the enzyme assays. VS and GF supervised this study and revised the manuscript. All authors have read, corrected and approved the final manuscript.}

\section{Acknowledgements}

Financial assistance was obtained from the Department of Science and Technology (South Africa), The Council for Scientific and Industrial Research, the University of Pretoria and The European Union (AgroCos FP7 project). The authors would like to acknowledge Mr. Frikkie Calitz for conducting statistical procedures.

This article is dedicated to the memory of Professor Andrew Marston who was the supervisor of Gugulethu Ndlovu at the time of his passing.

\section{Author details}

${ }^{1}$ Natural Product Chemistry Group, Biosciences Unit, Council for Scientific and Industrial Research, P.O. Box 395, Pretoria (0001), South Africa.

${ }^{2}$ Department of Chemistry, University of Free-State, P.O. Box 339, Bloemfontein (9300), South Africa. ${ }^{3}$ Molecular and Biomedical Technologies, Biosciences Unit, Council for Scientific and Industrial Research, P.O. Box 395, Pretoria (0001), South Africa. ${ }^{4}$ Department of Pharmacology, University of Pretoria, Private Bag X323, Arcadia (0007), South Africa.

Received: 14 June 2013 Accepted: 28 October 2013 Published: 5 November 2013

\section{References}

1. Mukherjee PK, Maity N, Nema NK, Sarkarm BK: Bioactive compounds from natural resources against skin aging. Phytomedicine 2011, 19:64-73.

2. Fisher GJ, Kang S, Varani J, Bata-Csorgo Z, Wan J, Data S, Voorhees JJ: Mechanisms of photoaging and chronological skin aging. Arch Dermatol 2002, 138(11):1462-1470.

3. Maity N, Nema NK, Abedy S, Sarkar BK, Mukherjee PK: Exploring Tagetes erecta Linn flower for the elastase, hyaluronidase and MMP-1 inhibitory activity. J Ethnopharmacol 2011, 137:1300-1305.

4. Rittie L, Fisher GJ: UV-light-induced signal cascades and skin aging. Ageing Res Rev 2002, 1:705-720. 
5. Fulop T, Khalil A, Larbi A: The role of elastin peptides in modulating the immune response in aging and age-related diseases. Pathol Biol 2012, 60:28-33.

6. Kurtz A, Oh S-J: Age related changes of the extracellular matrix and stem cell maintenance. Prev Med 2012, 54:S50-S56.

7. Wary KK, Thakker GD, Humtsoe JO, Yang J: Analysis of VEGF-responsive genes involved in the activation of endothelial cells. Mol Cancer 2003, 2:25-36.

8. Losso JN, Munene CN, Bansode RR, Bawadi HA: Inhibition of matrix metalloproteinase-1 activity by the soybean Bowman-Birk inhibitor. Biotechnol Lett 2004, 26:901-905.

9. Manuskiatti W, Maibach H: Hyaluronic acid and skin: wound healing and aging. Int J Dermatol 1996, 35(8):539-544.

10. Hsu M-F, Chiang B-H: Stimulating effects of Bacillus subtilis natto-fermented Radix astragali on hyaluronic acid production in human skin cells. J Ethnopharmacol 2009, 125:474-481

11. Wang $\mathrm{K}-\mathrm{H}$, Lin R-D, Hsu F-L, Huang $\mathrm{Y}-\mathrm{H}$, Chang $\mathrm{H}-\mathrm{C}$, Huang $\mathrm{C}-\mathrm{Y}$, Lee $\mathrm{M}-\mathrm{H}$ : Cosmetic applications of selected traditional Chinese herbal medicines. J Ethnopharmacol 2006, 106:353-359.

12. Irshad M, Chaudhuri PS: Oxidant-antioxidant system: role and significance in human body. Indian J Exp Biol 2002, 40:1233-1239.

13. Labat-Robert J, Fourtanier A, Boyer-Lafargue B, Robert L: Age dependent increase of elastase type protease activity in mouse skin effect of UV-irradiation. J Photochem Photobiol B 2000, 57:113-118.

14. Sumantran VN, Kulkarni AA, Harsulkar A, Wele A, Koppikar SJ, Chandwaskar R, Gaire V, Dalvi M, Wagh UV: Hyaluronidase and collagenase inhibitory activities of the herbal formulation Triphala guggulu. J Biosci 2007, 32(4):755-761.

15. Bizimenyera ES, Aderogba MA, Eloff JN, Swan GE: Potential of neuroprotective antioxidant-based therapeutics from Peltophorum africanum Sond. (Fabaceae). Afr J Trad CAM 2007, 4(1):99-106.

16. Van Wyk B-E, Gericke N: People's plants: a guide to useful plants in southern Africa. Pretoria: Briza Publications; 2000.

17. Watt JM, Breyer-Brandwijk MG: The medicinal and poisonous plants of southern and eastern Africa. 2nd edition. London: Livingstone; 1962.

18. Kafua L, Kritzinger Q, Hussein A: Antifungal activity of Psychotria capensis leaf extracts [abstract]. S Afr J Bot 2009, 75(2):1.

19. Durling NE, Catchpole OJ, Grey JB, Webby RF, Mitchell KA, Foo LY, Perry NB: Extraction of phenolics and essential oil from dried sage (Salvia officinalis) using ethanol-water mixtures. Food Chem 2007, 101:1417-1424.

20. Karim AA, Rajeev B, Alothman M: Antioxidant capacity and phenolic content of selected tropical fruits from Malaysia, extracted with different solvents. Food Chem 2009, 115:785-788

21. Kraunsoe JAE, Claridge TDW, Lowe G: Inhibition of human leukocyte and porcine pancreatic elastase by homologues of bovine pancreatic trypsin inhibitor. Biochemistry 1996, 35:9090-9096

22. Moore S, Stein WH: Photometric ninhydrin method for use in the chromatography of amino acids. J Biol Chem 1948, 176:367-388.

23. Mandl I, MacLennan JD, Howes EL, DeBellis RH, Sohler A: Isolation and characterisation of proteinase and collagenase from CL. histolyticum. J Clin Invest 1953, 32:1323-1329.

24. Reissig JL, Strominger JL, Leloir LF: A modified colorimetric method for the estimation of $\mathrm{N}$-acetylamino sugars. J Biol Chem 1955, 217:959-966.

25. Takahashi T, Ikegami-Kawai M, Okuda R, Suzuki K: A fluorimetric MorganElson assay method for Hyaluronidase activity. Anal Biochem 2003, 322:257-263.

26. Re R, Pellegrinin N, Proteggente A, Pannala A, Yang M, Rice-Evans C: Antioxidant activity applying an improved $A B T S$ radical cation decolorization assay. Free Radic Biol Med 1999, 26:1231-1237.

27. Shapiro SS, Wilk MB: Analysis of variance test for normality (complete samples). Biometrika 1965, 52:591-611.

28. SAS Institute Inc: SAS/STAT User's Guide, version 9. Cary: North Carolina: 1st printing, volume 2; 1999

29. Glass GV, Peckham PD, Sanders JR: Consequences of failure to meet assumptions underlying the fixed effects analysis of variance and covariance. Rev Educ Res 1972, 42(3):237-288.

30. Tamburro AML: Elastin: molecular description and function. Int J Biochem Cell B 1999, 31:261-272

31. Xu G-H, Kim Y-H, Chi S-W, Choo S-J, Ryoo I-J, Ahn J-S, Yoo I-D: Evaluation of human neutrophil elastase inhibitory effect of iridoid glycosides from Hedyotis diffusa. Bioorgan Med Chem Lett 2010, 20:513-515.
32. Wu S-F, Hwang T-L, Chen S-L, Wu C-C, Ohkoshi E, Lee K-H, Chang F-R, Wu Y-C: Bioactive components from the heartwood of Pterocarpus santalinus. Bioorgan Med Chem Lett 2011, 21:5630-5632.

33. Lee C-L, Liao Y-C, Hwang TL, Wu C-C, Chang F-R, Wu Y-C: Ixorapeptide I and ixorapeptide II, bioactive peptides isolated from Ixora coccinea. Bioorgan Med Chem Lett 2010, 20:7354-7357.

34. Chiang H-M, Lin T-J, Chiu C-Y, Chang C-W, Hsu K-C, Fan P-C, Wen K-C: Coffea arabica extract and its constituents prevent photoaging by suppressing MMPs expression and MAP kinase pathway. Food Chem Toxicol 2011, 49:309-318.

35. Sgariglia MA, Soberon JR, Cabanes AP, Sampietro DA, Vattuone MA Anti-inflammatory properties of phenolic lactones isolated from Caesalpinia paraguariensis stem bark. J Ethnopharmacol 2013, 147:63-73.

36. Manaharan T, Teng LL, Appleton D, Ming CH, Masilamani T, Palanisamy UD: Antioxidant and antiglycemic potential of Peltophorum pterocarpum plant parts. Food Chem 2011, 129:1355-1361.

37. Pavagadhi S, Joseph GS, Jena BS: Antioxidant principles in Peltophorum ferrugineum flower extracts. Int J Food Prop 2012, 15:549-557.

38. Bahia MV, David JM, Rezende LC, Guedes MLS, David JP: A C-glucoside benzoic acid derivative from the leaves of Peltophorum dubium. Phytochem Lett 2010, 3:168-170.

39. Poullain C, Girard-Valenciennes E, Smadja J: Plants from reunion island: evaluation of their free radical scavenging and antioxidant activities. J Ethnopharmacol 2004, 95:19-26.

40. Arokiyaraj S, Sripriya N, Bhagya R, Radhika B, Prameela L, Udayaprakash NK. Phytochemical screening, antibacterial and free radical scavenging effects of Artemisia nilagirica, mimosa pudica and Clerodendrum siphonathus - an in-vitro study. Asian Pac J Trop Biomed 2012, 2(Suppl 2):S601-S604.

41. Jadeja RN, Thounaojam MC, Singh TB, Devkar RV, Ramachandran AV: Traditional uses, phytochemistry and pharmacology of Clerodendron glandulosum Coleb - a review. Asian Pac J Trop Med 2012, 5(1):1-6.

42. Adewusi EA, Moodley N, Steenkamp V: Antioxidant and acetylcholinesterase inhibitory activity of selected southern African medicinal plants. S Afr J Bot 2011, 77:638-644.

43. Steenkamp V, Grimmer H, Semano M, Gulumian M: Antioxidant and genotoxic properties of South African herbal extracts. Mutat Res 2005, 581:35-42.

44. Glasby JS: Dictionary of plants containing secondary metabolites. London: Taylor and Francis; 1991

45. Nascimento NC, Fragoso V, Moura DJ, Romano e Silva AC, Fett-Neto AG, Saffi J: Antioxidant and antimutagenic effects of the crude folia extract and the alkaloid brachycerine of Psychotria brachyceras. Environ $\mathrm{Mol}$ Mutagen 2007, 48:728-734.

46. Fragoso V, Nascimento NC, Moura DJ: Antioxidant and antimutagenic properties of the monoterpene indole alkaloid psychollatine and the crude folia extract of Psychotria umbellata Vell. Toxicol in vitro 2008, 22:559-566

47. Saha K, Lajis NH, Israf DA, Hamzaf AS, Khozirah S, Khamis S, Syahida A: Evaluation of antioxidant and nitric oxide inhibitory activities of selected Malaysian medicinal plants. J Ethnopharmacol 2004, 92:263-267.

doi:10.1186/1472-6882-13-304

Cite this article as: Ndlovu et al.: In vitro determination of the anti-aging potential of four southern African medicinal plants. BMC Complementary and Alternative Medicine 2013 13:304.

\section{Submit your next manuscript to BioMed Central and take full advantage of:}

- Convenient online submission

- Thorough peer review

- No space constraints or color figure charges

- Immediate publication on acceptance

- Inclusion in PubMed, CAS, Scopus and Google Scholar

- Research which is freely available for redistribution 